\title{
Large vocal cord polyp: an unusual cause of dyspnoea
}

\author{
Gurshinderpal Singh Shergill, ${ }^{1}$ Ankur Kaur Shergill ${ }^{2}$
}

'Department of ENT Head and Neck Surgery, Kasturba Medical College, Manipal University, Manipal, Karnataka, India

${ }^{2}$ Department of Oral Pathology and Microbiology, Manipal College of Dental Sciences, Manipal University, Manipal, Karnataka, India

\section{Correspondence to} Dr Gurshinderpal Singh Shergill,

shergill243@gmail.com

Accepted 23 August 2015

\section{(1) cossanak}

To cite: Shergill GS, Shergill AK. BMJ Case Rep Published online: [please include Day Month Year] doi:10.1136/bcr-2015211542

\section{DESCRIPTION}

A 65 -year-old woman presented to the pulmonary medicine department of Kasturba Hospital with dyspnoea and dysphonia of 3 months duration. She reported that her dyspnoea was aggravated in the supine position. The patient had consulted a local physician at a peripheral centre for the same symptom, and was diagnosed as a case of asthma. She was prescribed oral steroid inhalers and intravenous steroids. She reported being temporarily relieved of her symptoms after administration of the steroid injections. Subsequently, she was referred to the department of pulmonary medicine in our hospital. The patient was carefully examined and referred to the department of ENT and head and neck surgery for further laryngeal examination in view of the dysphonia. Indirect laryngoscopy examination revealed a large, soft, pedunculated polyp nearly covering the entire laryngeal inlet. Further, on video laryngoscopic examination, the large vocal cord polyp was seen to be arising from the left vocal cord, virtually blocking the glottis, with minimal residual airway at the posterior laryngeal inlet (figure 1). The polyp was drawn inside the subglottic area during inspiration, leading to breathing difficulty and cough (video 1). The patient was immediately posted for microlaryngoscopic (MLScopy) excision of the polyp, under general anaesthesia. On the basis of the discussion with the anaesthetists, and considering the size and location of the polyp, tracheostomy was preferred over endotracheal intubation for securing the airway for general anaesthesia, as the latter could promptly dislodge the polyp. Tracheostomy was performed followed by MLScopy excision of the polyp. Decannulation was carried out on the

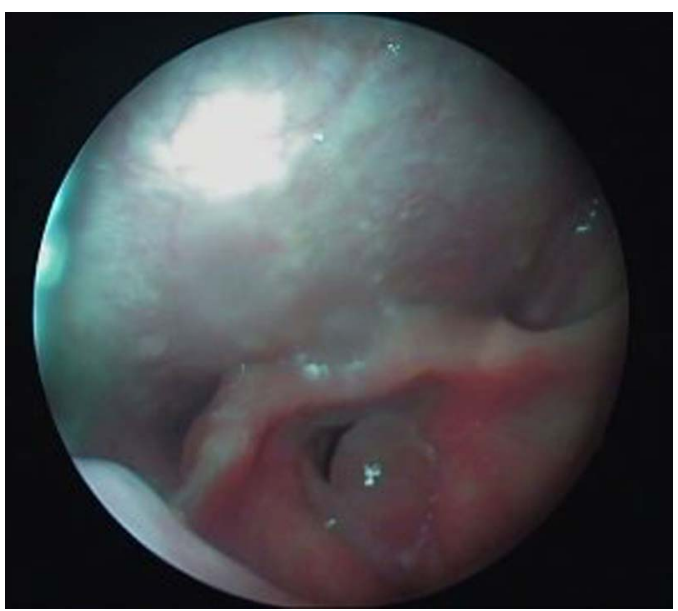

Figure 1 Video laryngoscopic image showing vocal cord polyp almost obstructing the glottis.

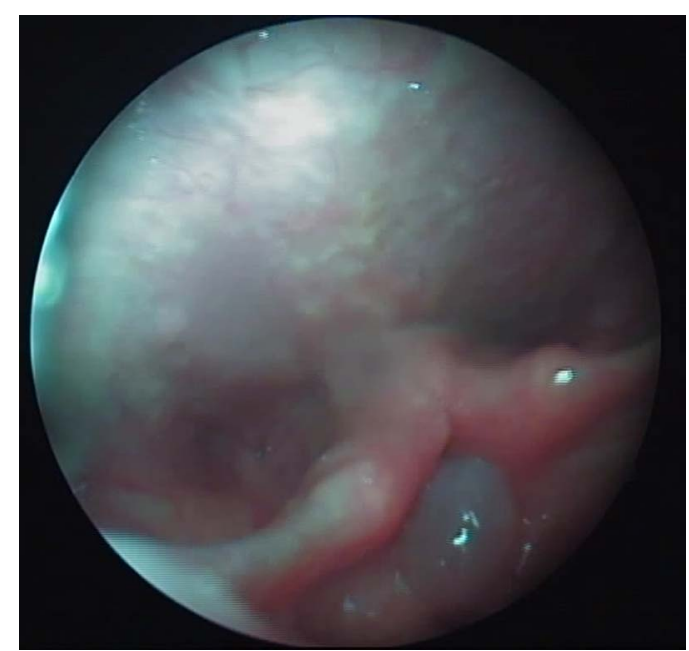

Video 1 Video laryngoscopic video showing large left vocal cord polyp moving with respiration and causing dyspnoea.

third postoperative day. Healing was uneventful and the patient was completely relieved of the presenting symptoms, with almost normal vocal cords (video 2).

Vocal cord benign inflammatory polyps are common, but respiratory sequelae caused by their presence are rare and death by airway obstruction due to the large laryngeal polyp is very unusual. A rare case of death due to a large laryngeal polyp has been reported in the literature. ${ }^{12}$ The primary symptom indicating the presence of a vocal cord polyp is usually dysphonia, and the cases with respiratory symptoms reported are often extremely misleading. ${ }^{1}$ In the majority of cases, tracheostomy

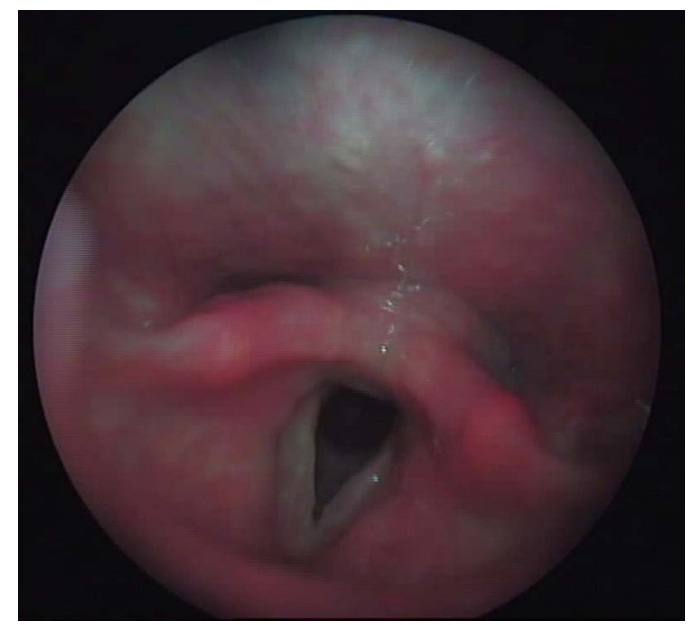

Video 2 Postsurgery video laryngoscopic video showing normal vocal cords. 
forms the prime modality to secure the airway for administering general anaesthesia, as endotracheal intubation can be risky and lead to dislodgement of the polyp, causing acute airway

\section{Learning points}

- Large vocal cord polyps can present primarily with respiratory symptoms such as respiratory distress and asthma. Clinicians should be well aware of the probability of vocal cord polyps and referral to a otolaryngologist should be made in all suspicious cases.

- Meticulous treatment planning by surgeon and anaesthetist should be mutually carried out prior to microlaryngoscopic excision in cases of large vocal cord polyps causing airway obstruction. obstruction. ${ }^{3}$ Microlaryngoscopic excision of the polyp is the preferred treatment.

Acknowledgements The authors would like to acknowledge the departments of pulmonary medicine and anaesthesia for their constant support and guidance.

Competing interests None declared.

Patient consent Obtained.

Provenance and peer review Not commissioned; externally peer reviewed.

\section{REFERENCES}

1 Tsunoda A, Hatanaka A, Watabiki N, et al. Suffocation caused by large vocal cord polyps. Am J Emerg Med 2003;22:63-4.

2 Tanguay J, Pollanen M. Sudden death by laryngeal polyp: a case report and review of the literature. Forensic Sci Med Pathol 2009;5:17-21.

3 Okami K, Hamano T, Sakai A, et al. Airway management during the laryngoscopic surgery for the benign laryngeal obstructive disease. Tokai I Exp Clin Med 2004;29:123-6.

Copyright 2015 BMJ Publishing Group. All rights reserved. For permission to reuse any of this content visit http://group.bmj.com/group/rights-licensing/permissions.

BMJ Case Report Fellows may re-use this article for personal use and teaching without any further permission.

Become a Fellow of BMJ Case Reports today and you can:

- Submit as many cases as you like

- Enjoy fast sympathetic peer review and rapid publication of accepted articles

- Access all the published articles

- Re-use any of the published material for personal use and teaching without further permission

For information on Institutional Fellowships contact consortiasales@bmjgroup.com

Visit casereports.bmj.com for more articles like this and to become a Fellow 